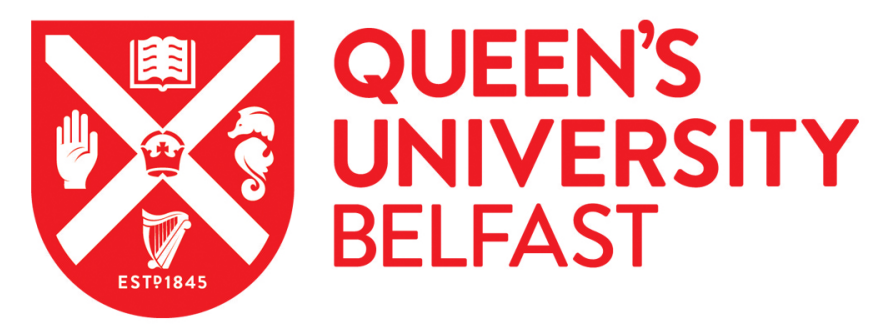

\title{
Political constructions of a cross-community identity in a divided society: how politicians articulate Northern Irishness
}

McNicholl, K. (2017). Political constructions of a cross-community identity in a divided society: how politicians articulate Northern Irishness. National Identities. https://doi.org/10.1080/14608944.2017.1312325

\author{
Published in: \\ National Identities
}

Document Version:

Peer reviewed version

Queen's University Belfast - Research Portal:

Link to publication record in Queen's University Belfast Research Portal

Publisher rights

(c) 2017 Informa UK Limited, trading as Taylor \& Francis Group.

This work is made available online in accordance with the publisher's policies. Please refer to any applicable terms of use of the publisher.

\section{General rights}

Copyright for the publications made accessible via the Queen's University Belfast Research Portal is retained by the author(s) and / or other copyright owners and it is a condition of accessing these publications that users recognise and abide by the legal requirements associated with these rights.

Take down policy

The Research Portal is Queen's institutional repository that provides access to Queen's research output. Every effort has been made to ensure that content in the Research Portal does not infringe any person's rights, or applicable UK laws. If you discover content in the Research Portal that you believe breaches copyright or violates any law, please contact openaccess@qub.ac.uk. 


\section{Political Constructions of a Cross-Community Identity in a Divided Society:}

\section{How Politicians Articulate Northern Irishness.}

A shared identity has been shown to reduce prejudice between conflicting social groups. One such common national category is the 'Northern Irish' identity which can be inclusive of both Catholics and Protestants. This study analyses the plenary sessions of the Northern Ireland Assembly to show how the national category 'Northern Irish' is framed by politicians. Content analysis shows that it is used more often by centrist parties who tend to frame it positively and as part of their political viewpoint. There is also evidence of the instrumental use of this identity by unionists in line with the ingroup projection model. 


\section{Introduction}

New national identities are extremely rare, and even impossible according to some definition of the nation (Smith, 1991, Stalin, 1913). In spite of this, and in spite of having no institutional support, shared history, common religion, language, flag, national anthem, unique culture, traditions of state, or any of the customary trappings of national belonging, a new national category has appeared in in a society deeply divided by an intractable national conflict: the Northern Irish identity. The first mention of a Northern Irish identity that is distinct from the traditional binary of Irish and British was in an interview with peace campaigners in 1976:

"Miracles have been happening in Northern Ireland and we have a new vision for Northern Ireland where people will put aside violence, where they will come together to build together one community out of our now divided community, where they will begin to see themselves not as Southern Irish people and not as British people, but as Northern Irish people with a complete new identity.”

(MacNeil, 1976)

Since then there has been a small body of research on this identity which is currently claimed by approximately one quarter of both Catholics and Protestants in the region (ARK, 2014). There have however been inconsistent findings in previous studies attempting to understand the political significance of Northern Irish identification. While some, like in the quote above, see this as a common ingroup identity (Muldoon, Schmid \& Downes, 2009, Hayes \& McAllister, 2009, Lowe \& Muldoon, 2012), inclusive of members of both traditions and therefore it fits well with the aspirations of centrist parties in the region who tend to be explicitly anti-sectarian. Others emphasise its lack of importance for those who claim this identity (Trew, 1998, Hayes \& McAllister, 2013, Muldoon et al., 2007) and show that although it can be related to more positive social attitudes, there is no such relationship to a movement away from the political extremes. It has also been suggested that this identity can be a somewhat disingenuous 'safe label', or identity claim made by some who do not want to betray their national identity in a potentially conflictual intergroup contact situation (Todd et al., 2006). The present study aims to help the resolution of some of these tensions in the literature using content analysis of the Hansard record of plenary debates in the Northern Ireland Assembly. Hypotheses are formed and tested. It is shown that centrist parties are more likely to use the phrase 'Northern Irish' and are more likely to frame it as part of the 
rhetoric associated with their centrist politics. It is also shown that the term 'Northern Irish' is used less than other national categories such as 'Irish', 'British', 'Ulster', and even 'French'. This study then contributes to this debate on the political importance of the Northern Irish identity and on inclusive national identities in other divided societies.

\section{Background}

There is a debate within the literature regarding the relationship between Northern Irish identification and political attitudes and behaviours. Some argue that this identity is associated with a movement away from the political extremes and greater preference for centrist politics (Tonge \& Gomez, 2015). From this perspective, identifying oneself as Northern Irish, rather than Irish or British, implies a decrease in the perceived salience of the traditional binary and the constitutional question that forms the major point of contestation between nationalist and unionist parties. Conversely, other research has proposed that, for several different reasons, the political impact of this identity is negligible. For instance McGlynn et al (2004) have shown that intergroup contact within a school environment can have an influence on identity but not necessarily political attitudes. The aim here is not to understand the party political preferences of Northern Irish identifiers as compared with their British and Irish counterparts. Rather it is to understand how each party uses and understands references to the Northern Irish category.

Several reasons have been put forward to suggest that Northern Irish identification should have strong political implications. Firstly, this identity has been shown to be associated with more positive attitudes towards the people and culture of out-group identities (Lowe \& Muldoon, 2014). Conforming to the theories of common ingroup identities (Gaertner \& Dovidio, 2012, Gaertner \& Dovidio, 2014), Northern Irish identifiers tend to have a greater level of contact with out-group members, suggesting that this identity is perceived to be inclusive of members of both communities such that the salience of political division is less profound for them when compared with Irish and British identifiers. As this is the most inclusive of the major national identity categories in the region (Moor et al., 2010) it can be expected these identifiers have preferences for parties that are moderate and centrist on the spectrum of unionist to nationalist. Recently, this inference has been supported using statistical analysis of survey data (Tonge \& Gomez, 2015). 
It has also been shown that there is a tendency for Northern Irish identifiers to live further from areas that have experienced higher levels of political violence (Lowe \& Muldoon, 2010), implying that their political attitudes are less focused on matters relating to the constitutional question. An analysis of qualitative data has indicated that one reason for this identity claim among Catholics is due to disillusionment with the ideology of republicanism (Todd et al., 2006). Northern Irish identifiers also have greater optimism about the political future, considering it more likely that the sectarian divide will eventually loss its intractability (Devine \& Schubotz, 2004). This body of evidence points toward an expectation that Northern Irishness will be associated with centrist, cross-community parties.

In contrast to this assertion, other studies have indicated that the Northern Irish identity may have either a negligible moderating impact on political attitudes, or that this identity can be instrumentally used to advance nationalist or unionist political aspirations. Firstly, in apparent contradiction to other studies (Tonge \& Gomez, 2015), it has been shown that while Northern Irishness is associated with moderate social attitudes, that this is a separate phenomenon to political beliefs, which are not necessarily affected (Moxon-Browne, 1991, McGlynn et al., 2004). The political implications of this identity could be negated due to Northern Irishness being the weakest identity option in the region, with Irish and British identifiers tending to be more emphatic about their preferences (Trew, 1998). This could also explain the relatively limited political representation of centrist parties in the Assembly despite Northern Irish identifiers in the region being of a similar quantity to Irish identifiers (ARK, 2014).

Catholics in particular have been shown to be willing to opt for an inclusive social category, but without necessarily indicating agreement with partition (Moxon-Browne, 1991). Northern Irishness for them can imply that they are 'Irish, but from the North'. This can be considered a form of ingroup projection (Wenzel, Mummenday \& Waldzus, 2008) whereby ingroup characteristics are projected onto the superordinate identity for instrumental purposes. Similar projection effects have been discovered in the Scottish national identity (Sindic \& Reicher, 2008). Scottishness can be articulated in a manner that either emphasises similarity or difference to Britishness to justify attitudes towards independence. Alternative projection effects have been shown on the Northern Irish identity such that the prototypical Northern Irish identifier is perceived to be more likely to be Protestant rather than Catholic (McKeown, 2014). It has also been shown that Catholics tend to view Northern Irishness as 'closer' to Irishness and Protestants view it as closer to British (Waddell \& Cairns, 1991). 
This corpus of work then suggests that Northern Irish identification can either be used as a rhetorical resource by nationalists or unionists, or that that the centrist tendencies of Northern Irish identifiers are limited.

The specific research questions driving this research are:

Which parties use the term 'Northern Irish' most often?

How does each party frame 'Northern Irishness'?

What differences exist between moderate and less moderate nationalist and unionist parties?

\section{Parties in the Assembly}

The Northern Ireland Assembly is largely composed of five major parties who take 102 of the 108 seats. In accordance with the terms of the Good Friday/Belfast Agreement each party must designate as either 'nationalist', 'unionist' or 'other'. Unionist parties take 56 seats in the chamber and mainly attract voters from the Protestant community, and aspire to continuing the constitutional connection to the United Kingdom. Nationalist designated parties take 43 of these seats, tend to attract Catholic voters and in their manifestos include a commitment to Irish re-unification. A brief introduction to each party is given below, with a description of their history, unique policy objectives and how it is expected that they will use the concept of Northern Irishness as a rhetorical tool.

\section{Alliance}

The Alliance party is considered the most moderate, middle-ground of the major parties in the Assembly (Evans \& Duffy, 1997). Although committed to supporting the union with the United Kingdom (Whyte, 1991) it designates as 'other' in the Assembly. This is due to its explicitly desegregationist aspirations and calls for a 'shared future' (Alliance, 2016, Graham \& Nash, 2006). Historically, Alliance supporters have tended to come from a Protestant background (McAllister \& Wilson, 1978), but today it attracts roughly equal support from both Catholics and Protestants (ARK, 2014). The party is linked to the Liberal Democrat 
Party in Great Britain, and are members of the Liberal International (Liberal International, 2016).

It is expected that this party will have a greater preference for the expression 'Northern Irish' than any of the other main parties. As Northern Irish is considered the most inclusive of the national identity options in the region that can include member of both communities as well as those who do not feel themselves to be a member of either it seems that this would be an appealing category for them. In the last Northern Ireland Life and Times survey it was shown that $45.5 \%$ of Alliance supporters consider themselves to be primarily Northern Irish, which is more than any other of the other main parties (ARK, 2014). Furthermore, it is expected that Alliance members will articulate Northern Irishness as a part of their explicitly centrist political project more than other parties. This centrist agenda is emphasised in the manifestos of this party (Alliance Party, 2011). Their focus on desegregation, antisectarianism and social unity between communities means that this formation of Northern Irishness should fit well with their aspirations.

\section{The Social Democratic and Labour Party}

In the 1970's the SDLP replaced the Nationalist Party as the voice of moderate, constitutional nationalism, and had a virtual monopoly on Catholics votes before the rise of Sinn Féin (Whyte, 1991). Along with the UUP, the SDLP was a principal architect of the Good Friday/Belfast Agreement and in spite of both party's leaders winning the Nobel Peace Prize for their efforts, the SDLP also lost their dominant position following the accord (Mitchell, Evans \& O’Leary, 2009). They are still considered the moderate nationalist party on account of their persistent stand against political violence throughout the conflict, as well as their criticism of the human rights abuses committed by security forces (Dixon, 2008).

Although designating as nationalist in the Assembly, the longstanding position of the SDLP is that reunification should only occur once the majority of people in Northern Ireland are in support of such a change (SDLP, 2016). This is a less emphatic call for unity than has previously been the case for Sinn Féin and is line with the views of their supporters, only 27.5\% of whom wish to see a United Ireland in the long-term (ARK, 2014). Rather than this, the SDLP have made calls for an 'Irish Dimension' to Northern Ireland through institutional connections with the government of the Irish Republic, and the granting of recognition of the 
Irish tradition within Northern Ireland (McLoughlin, 2008). On the basis of this it seems likely that the SDLP will be comfortable with the use of the phrase 'Northern Irish' when compared with Sinn Féin.

\section{The Ulster Unionist Party}

The UUP have their roots in the Official Unionist Party which dominated the Northern Ireland parliament from the creation of the state in 1921 until the imposition of direct rule in 1972 (Walker, 2004). During this period it had strong formal links with the Orange Order, a Protestant ethno-religious cultural organisation, although in recent decades the party has undergone some degree of modernisation in way similar to other European Christian Democratic parties (Evans \& Tonge, 2005). In the literature the UUP is described as the moderate counterpart to the historically more hard-line DUP (Garry, 2014). This is mainly due to its signing of the 1998 peace accord without the prerequisite of IRA decommissioning.

Jennifer Todd identifies two ideological strands within unionism, distinguishable by the boundaries of their respective imagined communities (1987). The UUP tends to reflect the constituency of those with an Ulster British ideology whereas the DUP is more closely related to what is termed Ulster loyalist ideology. Ulster British ideology views their community as Greater Britain and relegates Ulster Protestantism to a secondary concern. Ulster British ideology has its origin in the support for the civilising influence of the empire and as such has its adherents have a self-image of embodying British values such as liberalism, democracy and progressive social attitudes, when compared with Ulster loyalists. In spite of their relative lack of emphasis on regionalism (in contrast to the DUP) it is expected they will use this phrase more often due to its association with political moderation. However, due to this factor it is further predicted that they will be more likely than the DUP to use this phrase as an identity claim such that it is framed as one identity among several within the region rather than a superordinate identity that includes members of all communities. For them Northern Irishness will be framed as a subgroup within the superordinate British identity. 
The DUP was formed by the Rev Ian Paisley in 1971 as a radical party of protest for Ulster loyalists, mainly from working class communities (Southern, 2005). Todd explains that the DUP is heavily influenced by Ulster Loyalist ideology which is often expressed in feelings of isolation and threat as well as in the marches of Loyal Institutions and the importance of the Protestant faith (Todd, 1987). It is commonly suggested that Ulster Loyalism suffers from a 'siege mentality' (McGladdery, 2002) and that the perceived alternative to Loyalist dominance is defeat and humiliation which could easily be brought about by the betrayal of the British government (Todd, 1987). This means that their loyalty to the United Kingdom is conditional, and their primary fidelity is to their own Ulster Protestant community.

Since signing up to the power-sharing executive along with the four other major parties, the DUP has become the largest of Northern Ireland's parties. The change from acting as an opposition force to becoming the dominant Unionist party, ethno-nationalist and religious rhetoric have become rare, and there are suggestions that this is a move towards liberalism on their part (Mitchell, Evans \& O’Leary, 2009). An interesting indication of this change is that the DUP's website and recent manifestos have no references to Protestantism, but rather focuses on creating a stable and prosperous Northern Ireland with a strengthened union with Great Britain (DUP, 2016).

Given their relative lack of political centrism it is expected the DUP will use the expression 'Northern Irish' less often than the UUP. However, their ideological link with regionalism means that it is likely they will use it more often than Sinn Féin. Also, this term is likely to be used instrumentally as a marker of differentiation with the Republic of Ireland. This would be evidence of ingroup projection as subgroup characteristics (in this case political unionism) are being projected onto the superordinate identity. Superordinate identities are common ingroup social identities, and so Northern Irish is expected to be framed as a unified people. This is in contrast to the UUP who are considered more likely to use it to indicate one possible form of identity claim among others.

\section{Sinn Féin}

Since the signing of the Good Friday/Belfast Agreement and the later commitment to the decommissioning of Provisional IRA weapons, Sinn Féin have succeeded in become a popular mainstream political party on both sides of the border (Evans \& Tonge, 2013). They 
have become the dominant voice of nationalists, and second party in the North with Martin McGuinness, one time commander of the Provisional IRA in Derry, taking the role of Deputy First Minister (Taylor, 2014). In spite of their abandonment of physical force republicanism, and signing up to the 'principle of consent' (meaning reunification can only occur when the majority in the region agree to it) their support comes almost entirely from the Catholic community, with Protestant support virtually non-existent (ARK, 2014).

Despite their engagement with constitutional politics in the region, their representatives tend to discursively ignore the state of Northern Ireland, preferring instead to use the phrase, 'North of Ireland', in the same way as many of the focus group participants in the previous chapter. For this reason it is expected that their MLA's will use the term extremely rarely, if at all. If they do use it, it will be most likely to refer to Northern Irishness as an identity claim, or label used by one group among many. Much of Sinn Féin’s rhetoric involves references to 'equality', so it may be helpful for them to acknowledge the Northern Irish as one of several minority groups. It would be unlikely they would frame Northern Irishness as a national category that is inclusive of all groups regardless of self-identification.

\section{Hypotheses}

From the previous synopsis of the history and aims of each of the main parties some predictions have been made about how each is considered likely to use and understand the expression 'Northern Irish'. These can be summarised so as to form hypotheses that relate to the overall research questions behind this study.

H1: Moderate parties will use the term 'Northern Irish' more often than less moderate parties.

Political centrism, or moderation, is the first factor expected to have an impact on each party's use of the term 'Northern Irish'. This is due to their desire for an inclusive category that members of both communities, and members of neither, can have an affinity to. It is expected that the Alliance party will use this phrase more than the other main parties, and that the UUP and SDLP will use it more often than either the DUP or Sinn Féin. 
H2: Centrist parties will use the term 'Northern Irish' as an explicitly anti-sectarian political project more than other parties.

The political agendas of moderate, centrist parties, and in particular the Alliance party, are very much in line with the political project theme found in the focus group data. This political project was understood to mean a move away from sectarianism and the traditional identity binary, so that people will prefer to consider themselves Northern Irish rather than Irish or British.

\section{Method}

Data

The data for this study comes from the entire Hansard record of the plenary sessions of the Northern Ireland Assembly which are publically available online (Hansard, 2015). The Northern Ireland Assembly is the devolved legislative body established in 1998 in accordance with the terms of the Good Friday/ Belfast Agreement. The institution was suspended four times due to cyclical crises, although two of these were for 24 hours only (Clarke \& Wilford, 2012). The longest suspension was between 2002 and 2007 following allegations of a Stormont spying ring run by Sinn Féin (McEvoy, 2007) although the Assembly did run from November 2006 to March 2007 as a 'transitional' body. This only amounts to a two data point gap in the analysis here so that there is no information for the 2003-2004 and 20042005 sessions.

\section{Analytic Procedure}

In order to test the first hypothesis, that moderate parties prefer the use of the national category, Northern Irish, the analysis of the text involves summative content analysis (Hsieh \& Shannon, 2005). This process involves “identifying and quantifying certain words or content in text with the purpose of understanding the contextual use of the words or content" (ibid, pg. 1283). Each use of the phrase 'Northern Irish' was identified in the text to ascertain how many times it was said, by whom, and which party they were a member of. The raw number of times each party uses the phrase is of limited value alone, as each party has a different level of representation in the assembly and so have varying opportunities to speak. This raw number was then divided by the total number of words spoken by each party 
between 2012 and 2015. The entire text of assembly debates from 2012-2015 is held in a Hansard database so the total number of words spoken was ascertained with the assistance of the Northern Ireland Hansard data service. An attempt was made to calculate the correct words uttered by each member from the period between 1998 and 2012 using MS Excel. However it was impossible to come to an accurate number without this being stored in a database. The sheer number of words used, and the different formatting used in each year, meant that that Excel had insufficient processing power. This is not ideal, but certainly gives a more valuable result than using the raw count alone.

The second hypothesis was tested by determining the proportion of each party's use of the phrase 'Northern Irish' that relates to a particularly anti-sectarian message. This analysis was facilitated by using resources from rhetorical psychology (Billig, 1996, Edwards \& Potter 1992). This perspective views the discourses of individuals as a rhetorical performance that attempts to persuade others. Concepts are constructed in a particular way in order to perform a function. The aim of the analysis is then to determine the particular constructions of Northern Irishness evident in text for each party, and what goals are being achieved. Each instance of the use of the phrase was read in its context in order to determine which of the four themes best described how it was understood. Each was then coded depending on whether or not it formed part of an anti-sectarian political discourse. They were also coded depending on whether the instance framed Northern Irishness as merely a geographical location, a common ingroup identity that is inclusive of all people in the region, or whether it referred to one group in the region who actively claimed this identity. The following analysis focuses primarily on the 'political project' code, but reference is also made to these other formations.

\section{Results}

\section{General findings}

Between 1998 and the end of 2015 the words 'Northern Irish' have been used a total of 154 times in the Northern Ireland Assembly. This is a remarkably low figure when compared with the other common national categories British (6149) and Irish (13111). This highlights a clear disparity between the use of identity talk in the legislative chamber and the identity preferences of the population. In 2014 24\% of people in the region indicated they most often 
thought of themselves as Northern Irish (ARK, 2014), however Northern Irish only accounts for $0.8 \%$ of the times local national identities are used in speech. Furthermore, only 62 of the 241 current and former Members of the Legislative Assembly have used this phrase (26\%). A breakdown of how often each party has used the term 'Northern Irish' as a proportion of the total number of words spoken by that party can be seen in Figure 1. Figure 2 shows what proportion of each party's current and former member have used the expression. These data are supportive of first hypothesis. In both these charts the parties are arranged from what is understood in the literature as 'less moderate nationalist' to 'less moderate unionist', with the most moderate parties in the centre (Garry, 2014). A clear bell curve is observable such that the more centrist parties are more inclined to say 'Northern Irish' than less moderate ones, Sinn Féin and the DUP. The breakdown for each party's use of the expression and how it is used as a rhetorical device differently for each is described below.

$<<<<<<$ Figure One about Here $>>>>>>>>$

$<<<<<<$ Figure Two about Here $>>>>>>>>$

\section{The Alliance Party}

The members of the Alliance party have used the phrase 'Northern Irish' more than any other party as a proportion of the total number of words they have used in the plenary sessions. They have used the term 46 times from 1998-2015 in a reasonably consistent annual frequency. Moreover, 6 of the party's members have used the phrase out of the 13 current and former members from this party that have taken seats in the Assembly (46.2\%). However, the use of the phrase is not equally distributed among these members, with one MLA, Kieran McCarthy accounting for just over half of these occurrences. In part, this can be attributed to this member's position as the Alliance spokesperson for Health, Social Services and Agriculture. For this reason many of this member's use of the term is in debates relating to agriculture, and so often refers to farmers in the region as Northern Irish.

Compared with the other main parties, Alliance tends to use the people and political project understandings of Northern Irishness to a greater degree than other parties as a proportion of their own usage (42.4\% and $6.8 \%$ respectively). Of the 24 occurrences that have been coded 
as an understanding of Northern Irishness as a social category of people, 8 of these have had references to sport. An illustrative example by the member, Chris Lyttle in 2015 in shown below:

"The success and achievements of the Northern Irish football team have inspired and united this community, I am glad to say, and I thank the Minister for acknowledging that and for agreeing that fans' embassies should be an important source of advice for fans in France.”

Although not overtly political, the choice of 'Northern Irish' rather than 'Northern Ireland' is here a rhetorical device with an implied anti-sectarian message. The use of the term is being associated with the unification of a divided society through a common support for the local team. A similar employment of the national category is found in this contribution from Kieran McCarthey in the 2011-2012 session.

"In the Minister's statement, he noted some well-known northern irish sporting heroes, of whose achievements we are all proud. However, in order to reach that status, people must start at grass-roots level, and Members must never forget those sportsmen and sportswomen who participate in their chosen sport, week in and week out. I take this opportunity to congratulate Ballycran hurling team, which clinched all this season’s championships. Also, Kircubbin Football Club [...]”

Northern Irish is here constructed as a superordinate common ingroup. Not only are all 'sporting heroes' from the region considered Northern Irish without consideration for the self-identity of each and commanding admiration from all sections of society, it is also framed so that it be inclusive of players of hurling, usually associated with Irishness, and footballers from a mainly unionist district. 
There are also 4 instances when the term is used as an explicitly political agenda, and so has been coded as a political project. For example, Eileen Bell in the 2001-2002 session states that

"We should stop referring to men, women or children as 'Loyalist', 'Republican', 'Catholic' or 'Protestant'. We should refer to people as fellow citizens, human beings or northern irish people.”

The use of Northern Irish as a rhetorical tool is the same here as in the previous examples, but in this case the meaning is not implied, but is given as an overt and 'hot' use of national identity. There is also a difference in that not only is the common ingroup identity advanced as something subgroup identifiers can support, but subgroup identification is considered problematic.

These findings support both hypotheses. The Alliance party, as the most moderate and centrist of the main parties, tends to use the Northern Irish more often (as a proportion of how often they speak) and are more likely to articulate it as a 'hot' political project.

\section{The Social Democratic and Labour Party}

Members of the SDLP have used this phrase 34 times and so are the second most likely to use the expression as a proportion of how often they speak. The phrase has been used by a total of 15 of the 44 current and former members of the party (34.1\%).

For the SDLP there is no evidence of the phrase being used as a political project. In a manner quite different to Sinn Féin, when referring to Northern Irish people, the SDLP do articulate this as a superordinate term, meaning all people in the region. This is an implied meaning without explicit mention of both communities:

"I would like to draw the Member's attention to the fact that the cost of treating individuals who need cardiac surgical operations in the North of Ireland in 2009-2010 
was $£ 17 \cdot 2$ million, plus $£ 3$ million for treating northern irish patients in the Republic, and $£ 0 \cdot 7$ million for treatment of our patients in the UK."

(Mark Durkin, 2011-2012)

"The most important thing is that the Budget will now be administered by local Ministers, which will help to reassure the northern irish public that local issues will actually be addressed.”

(Patricia Lewsley, 2000-2001)

Northern Irish is here used as a description of people, not as a self-identity, but rather a description of all people who live in the region. This is framed as a common ingroup identity, inclusive of all people from Northern Ireland. The geographical basis for the salience of this social identity is also seen in this extract from a debate on the future of the local broadcaster Ulster Television (UTV).

"Northern Ireland is not the same as London -people here value local content and proper analysis from a northern irish perspective. The people of Northern Ireland expect UTV to get into serious dialogue with the trade unions in relation to the impact on jobs."

(Pat Ramsey, 2008-2009)

The SDLP, as the moderate nationalist party uses similar themes as Alliance, albeit without an implied or explicit political project. The Northern Irish can exist as one people among many in the region, or as a descriptor of all those living here regardless of self-identity.

On 4 occasions the SDLP refer to Northern Irishness as an identity claim. Again, an interesting example of this comes from a debate on football. The debate relates to whether or not local players should be given the choice to play for the Republic of Ireland team: 
"For far too long in Northern Ireland, we have been telling one another what we are and we have been forcing one another to be something we are not. It is time that we allowed ourselves the freedom and space to be what we want to be - British, Irish, northern irish, or any combination of those. Frankly, it is none of the Assembly's business which team a player chooses to play for; and, given the complexity of the relationships on these islands, the Assembly should be protecting the freedom of individual players to choose for themselves.”

(Pat Ramsey, 2007-2008)

The construction of Northern Irishness as an identity claim is here used instrumentally so that Irish identifiers are not forced to play for a national team they do feel no affiliation with. Both sides of this debate construct Northern Irish as either a superordinate identity or as a label of self-identity in order to achieve particular rhetorical goals. Both appeal to Northern Irishness as progressive but in qualitatively different ways in order to further a political aspiration. Whereas the UUP frame Northern Irishness as an identity claim to emphasise peaceful coexistence of diverse identity groups within the state of Northern Ireland, the SDLP use it to legitimise the choice of Irishness within the region.

As the SDLP is the most moderate nationalist party, the quantity of use of this phrase as a proportion of their total speech supports the first hypothesis. In the same way as Alliance, they tend to use the term as a superordinate identity, inclusive of both communities regardless of self-identity.

\section{Ulster Unionist Party}

After the Alliance and SDLP, the UUP are the third most likely to use the phrase as a proportion of the total number of words they have said in the Assembly, using it 31 times. It has been used by 17 members of the 42 current and former Ulster Unionist MLAs (40.5\%). These occurrences are well distributed among members, with Danny Kinahan using the phrase most often (6 times).

The UUP tends to use the phrase to refer to Northern Ireland as a place or as a common ingroup in a similar way to the overall average for the entire assembly. What sets them 
somewhat apart from the DUP is that some references to 'Northern Irish people' have been coded as an identity claim. For example, Danny Kinahan in the 2012-2013 session says:

\begin{abstract}
"We need to learn from it and think our way through it so that we have as good and as all-encompassing a tourist initiative as we can. For example, we should target the northern irish people and the Ulster people around the UK and the rest of the world to get them to help us with our jobs. We should also support our airports here.”
\end{abstract}

This is what differentiates the UUP from the DUP. Even when referring to the Northern Irish as a people, this is occasionally framed as one group of people among many within Northern Ireland, rather than a single, unitary category that encompasses both Irish and British identifiers. There is no implied political project in this usage as Northern Irishness is not put forth as an alternative to identity division. To a larger degree than Alliance they appear to articulate Northern Irishness as another social group within a diverse region of the United Kingdom. The Northern Irish people are people who claim this identity for themselves.

There is one occasion when Northern Irishness is coded as a political project in a debate relating to World War One. The content of this political project is evidently quite different to that envisioned by the Alliance party:

"Irishman, at that stage, fought beside Irishman. They fought for Ireland and for Ulster. Ancient enmities were set aside, and the foundations of the northern irish state were created.”

(Michael Copeland, 2012-2013).

The Northern Irish state is suggested to have been created at a time when there was unity between communities fighting a common foe. This is in contrast to the Alliance's project that attempts to use Northern Irishness to reduce the salience of the identity binary. In this case it is enough that Northern Irishness is inclusive of both traditions without any suggestion 
that it should replace them. It is sufficient to have enmities set aside, but not subgroup identity.

It is evident then that although the Ulster Unionists conceptualise the Northern Irish as a common ingroup and as a political project that both of these articulations are qualitatively different those of the Alliance party. As a relatively moderate party they do however use a formation of Northern Irishness that can act as a rhetorical tool that emphasises peaceful coexistence, although it does not going quite so far as the centrist Alliance party's implied social unity. This formation, and the number of times they use the phrase relative to other parties support our first three hypotheses.

\section{The Democratic Unionist Party}

DUP members have used the phrase 'Northern Irish' 23 times in the life span of the Assembly in a consistent pattern over time. A total of 14 members have used the phrase out of the 61 current and former members (23\%). The recently appointed leader of the DUP, Arlene Foster has used the expression twice as often as any of her colleagues (6 times), although on 4 of these occasions it was used to refer to an organisation called 'Northern Irish Connections'.

Unlike the parties discussed previously the DUP do not use the term as a political project or as an identity claim, exclusively using the expression to refer to Northern Irishness as a place or a people. Their reference to Northern Irish people is similar to the superordinate formation, in that it is used to refer to all people in the region regardless of their self-identity. This is Northern Irishness as a common ingroup that is inclusive of Irish and British identifiers. However, this use of the term is occasionally used instrumentally in order to differentiate the region from the Republic of Ireland.

"When we send Ministers down to the Republic, we expect them to represent their people - northern irish people - to try to make sure that we promote Northern Ireland and get the best benefit for Northern Ireland in any situation. Why would we want to promote Galway, Limerick, Dublin and everywhere else, in either business or tourism, if we do not get a direct input into it?” 
(Paul Frew, 2011-2012)

“That debate resulted from my travelling out from Belfast International Airport last summer and noticing that the shops in the departure area were not marketing specifically northern irish goods. The products in those shops were branded as Irish, with Celtic or Guinness logos, and everything from leprechauns to shillelaghs to shamrocks. Northern Ireland should be marketed as a destination of its own. The Irish Republic is our economic competitor, and we should recognise the constitutional reality and ensure that Northern Ireland is marketed as a single entity so that our hotels and bed-and-breakfast establishments can benefit from tourism and not lose out to the South.”

(Alastair Ross, 2007-2008)

These extracts were coded as Northern Irishness as a geographical location, but there is certainly an implied political project underlying this usage. The political project is however quite different to that of the Alliance party. It is a project to resolve division in the region, but this resolution is viewed as the recognition of 'the constitutional reality' rather than a liberal acceptance of difference that is more evident in the rhetoric of the other parties.

Hypothesis 1 is supported in these results. Not only do the DUP use the term 'Northern Irish' less often than their more moderate counterpart, the UUP but they use it in a qualitatively different way. On the surface they do use it as an inclusive identity, but this appears as a rhetorical device to emphasise the constitutional separation between Northern Ireland and the Republic of Ireland. This is evidence of ingroup projection onto the superordinate identity. The common ingroup is inclusive of both Catholics and Protestants, but it is used to emphasise separation from Irishness, and the constitutional connection with Britain. The degree to which this can be considered a truly inclusive identity is then limited.

\section{Sinn Féin}

As predicted, the term 'Northern Irish' is virtually unused by Sinn Féin. The primary objective of this party is Irish reunification and so references to Northern Ireland at all could be seen as normalisation of partition. In the same way as many of the focus group's 
participants in the previous chapter, Sinn Féin members prefer the term, 'the north of Ireland'. However, on 6 occasions they do use the phrase in an instrumental manner. This was used by 3 of their 57 current and former members (5.2\%) The first four are by a single member, Mick Murphy in the 2000-2001 and 2001-2002 sessions. This extract includes three of these, and occurs in a debate on the foot-and-mouth crisis in 2000-2001:

"The Minister will be aware that northern irish beef is tagged as being UK sourced. I propose that when marketing northern irish beef in future, the UK tag should be changed to a northern irish tag. Does the Minister agree?”

These instances have been coded as Northern Irishness as place, but in way similar to the DUP, it is being used for a political purpose. Northern Irishness is here employed to initiate a bureaucratic separation between the United Kingdom and Northern Ireland. This is the only instrumental place based use of Northern Irishness by the party and the term remains unused until the 2013-2014 session and then again toward the end of 2015. In both these cases the term is used as an identity label used by one group of people within Northern Ireland.

“The Good Friday Agreement was about parity of esteem. It identified that people here can be British, they can see themselves as northern irish and they can see themselves as Irish. That is equality. I think that, unfortunately, Alliance has its eye more on the upcoming local government elections and unionist transfers than on equality and parity of esteem.

(Daithi McKay, 2013-2014)

Rather than framing Northern Irishness as a superordinate identity in a way similar to the SDLP, the Northern Irish are here presented as one identity group among others. This is closer to the UUP conceptualisation. The extract comes from a debate about the flying of the Union Flag on public buildings. The emphasis on the diversity of identities is here a rhetorical tool to reject the use of the symbols of Britishness. 
Again, hypothesis 1 is supported by the relative lack of use of this term by Sinn Féin compared with the more moderate parties. Hypothesis 4 is also supported, because Northern Irishness is not framed as a superordinate social identity inclusive of both communities and when there is a political instrumentality in the use of the phrase is different from that of the Alliance party. There is certainly ingroup projection on the part of Sinn Féin to construct Northern Irishness as different from Britishness, but this occurs very rarely. There is a large difference between Sinn Féin and SDLP in terms of the quantity of usage that is not seen between the DUP and the UUP.

\section{Discussion}

Previous research looking at the Northern Irish identity has made claims that are apparently inconsistent. Some claimed that this identity was related to changes in political attitudes, while others suggested that Northern Irish identification need not be associated with a change in political opinions. The aim of this paper was to begin to understand the relationship between the Northern Irishness and political attitudes by seeing how each party uses and understands the term. From an analysis of each party's particular aspirations, hypotheses were formed predicting how each should use and understand the term. Below each of the hypotheses are briefly described and are put against the results of the analysis to see how well they resonate with this study's findings. The major findings are then discussed in relation to the current literature to show how they help explain some of the apparently inconsistent results found in previous work. This is followed by a description of the implications of these findings and a call for further research.

H1: Moderate parties will use the term 'Northern Irish' more often than less moderate parties.

The first hypothesis predicts that parties closer to the political centre will prefer the use of the term 'Northern Irish'. The basis for this prediction comes from the literature on moderate political attitudes and Northern Irish identification (Tonge \& Gomez, 2015). Relative to Irish and British, Northern Irish is perceived to be the most inclusive category, and one that suggests ambivalence to the constitutional question that forms to fulcrum of division within the Assembly chamber (Moor et al., 2010). 
A calculation of how often each party uses this phrase as a proportion of how many words they have spoken in total supports this hypothesis. The claim is also given weight from the proportion of each party's MLA's have used the term. A greater proportion of members from moderate parties, and the Alliance party in particular, use the term when compared with the less moderate DUP and Sinn Féin. A graphical illustration of these findings can be found in Figure 1 and Figure 2.

H2: Centrist parties will use the term 'Northern Irish' as an explicitly anti-sectarian political project more than other parties.

The results of the analysis give at least partial support to this hypothesis. The Alliance party is the only major party that gave any articulation of a political project conceptualisation of Northern Irishness that resonates with that mentioned in the focus groups. The minor centrist parties, NI21 and the Green party also articulate Northern Irishness in this way. Other parties do use it in a manner that advances their own particular policy agendas, but it is only Alliance, the Greens and NI21 that use the expression in a way that emphasises the importance of this identity becoming prominent over time. However, out of the 44 occasions the party uses the phrase, they only frame Northern Irishness as a political project 4 times. Although more than any other party, this is perhaps too small a number to be able to make very firm conclusions.

\section{Implications for the understanding of the Northern Irish identity}

These findings have several implication for the study of this new national identity. Firstly, the fact that this identity is used so little by politicians when compared with the other categories of 'Irish', 'British', and 'Ulster', supports those who claim that this identity is not of significant political relevance to be likely to have a large impact on the future of politics in the region. Northern Irishness is simply not a constituency that demands substantial recognition from the elected representatives in the Northern Ireland Assembly.

On the other hand, the results do support those claims made by Tonge \& Gomez (2015), that Northern Irish identification is related to centrist party politics. While their claims were based on the analysis of survey data, this study uses qualitative data to show that centrist 
parties, and the Alliance party in particular, can use this social category as part of their political rhetoric to make salience a common ingroup that is explicitly inclusive of members of both traditions.

This analysis has shown the value of systematic analysis of parliamentary debates in order to better understand party positions on this identity. There is however a clear lacuna in the literature with regard to the different meanings that are attached to the Northern Irish social identity. Future work using qualitative methods could add a valuable contribution by looking specifically at the discourses of ordinary citizens to see how they use and understand Northern Irishness.

\section{References}

Alliance Party 2011, Alliance 2011 - 2015 Legislative Programme for Government. Available: $\quad$ http://allianceparty.org/document/manifesto/alliance-2011-2015-legislativeprogramme-for-government.pdf.

Alliance Party 2016, Alliance Party Website. Available: http://allianceparty.org/.

ARK. (2014). Northern Ireland life and times survey. Retrieved from www.ark.ac.uk/nilt

Billig, M. 1996, Arguing and thinking: A rhetorical approach to social psychology, Cambridge University Press.

Clark, A., \& Wilford, R. (2012). Political institutions, engagement and outreach: The case of the Northern Ireland assembly. Parliamentary Affairs, 65(2), 380-403.

Devine, P. \& Schubotz, D. 2004, "Us and them?" Your church, vol. 8, no. 5, pp. 6.

Dixon, P. 2008, Northern Ireland: the politics of war and peace, Palgrave Macmillan.

DUP 2016, DUP Official Website. Available: http://www.mydup.com/.

Edwards, D. \& Potter, J. 1992, Discursive psychology, Sage.

Evans, G. \& Duffy, M. 1997, "Beyond the sectarian divide: The social bases and political consequences of nationalist and unionist party competition in Northern Ireland", British journal of political science, vol. 27, no. 01, pp. 47-81. 
Evans, J, and Tonge, J. "Problems of Modernizing an Ethno-Religious Party: The Case of the Ulster Unionist Party in Northern Ireland." Party Politics 11.3 (2005): 319-338.

Evans, J. \& Tonge, J. 2013, "From abstentionism to enthusiasm: Sinn Fein, nationalist electors and support for devolved power-sharing in Northern Ireland", Irish Political Studies, vol. 28, no. 1, pp. 39-57.

Gaertner, S. L., \& Dovidio, J. F. (2012). Common ingroup identity model. The Encyclopaedia of Peace Psychology,

Gaertner, S. L., \& Dovidio, J. F. (2014). Reducing intergroup bias: The common ingroup identity model Psychology Press.

Garry, J. (2014). Potentially voting across the divide in deeply divided places: Ethnic catchall voting in consociational Northern Ireland. Political Studies, 62(1 suppl), 2-19.

Graham, B. \& Nash, C. 2006, "A shared future: territoriality, pluralism and public policy in Northern Ireland", Political Geography, vol. 25, no. 3, pp. 253-278.

Hansard 2015, Official Report of the Northern Ireland Assembly. Available: http://archive.niassembly.gov.uk/record/hansard_archive.htm.

Hayes, B. C., \& McAllister, I. (2009). Religion, identity and community relations among adults and young adults in Northern Ireland. Journal of Youth Studies, 12(4), 385-403.

Hayes, B. C., \& McAllister, I. (2013). Conflict to peace: Politics and society in Northern Ireland over half a century Oxford University Press.

Hsieh, H.F. \& Shannon, S.E. 2005, "Three approaches to qualitative content analysis", Qualitative health research, vol. 15, no. 9, pp. 1277-1288.

Liberal International 2016, Available: http://www.liberalinternational.org/site/Full_Members.html.

Lowe, R.D. \& Muldoon, O.T. 2010, "Religious and ethnonational identification and political violence", Ethnopolitics, vol. 9, no. 1, pp. 71-83.

Lowe, R. D., \& Muldoon, O. (2012). 'Unexpected' and 'Inclusive' Social identities in intractable conflict: The case of Northern Ireland. Representations of peace and conflict (pp. 187-204) Springer. 
Lowe, R. D., \& Muldoon, O. T. (2014). Shared national identification in Northern Ireland: An application of psychological models of group inclusion post conflict. Group Processes \& Intergroup Relations, , 1368430214525808.

MacNeil, R. (1976). Irish Women`s peace movement, PBS News Hour for October 5, 1976.

McAllister, I. \& Wilson, B. 1978, "Bi-confessionalism in a confessional party system: the Northern Ireland alliance party", Economic and Social Review, vol. 9, no. 3, pp. 207.

McEvoy, J. 2007, "The Northern Ireland Assembly election 2007", Irish political studies, vol. 22, no. 3, pp. 367-381.

McGladdery, G. 2002, "Perceptions of 'Siege Mentality': Northern Irish Protestants and White South Africans in the New Political Dispensation", Irish Studies in International Affairs, , pp. 87-103.

McGlynn*, C., Niens, U., Cairns, E. \& Hewstone, M. 2004, "Moving out of conflict: The contribution of integrated schools in Northern Ireland to identity, attitudes, forgiveness and reconciliation", Journal of Peace Education, vol. 1, no. 2, pp. 147-163.

McKeown, S. (2014). Perceptions of a superordinate identity in Northern Ireland. Peace and Conflict: Journal of Peace Psychology, 20(4), 505.

McLoughlin, P. 2008, "' Humespeak": the SDLP, political discourse, and the Northern Ireland peace process".

Mitchell, P., Evans, G. \& O'leary, B. 2009, "Extremist outbidding in ethnic party systems is not inevitable: tribune parties in Northern Ireland", Political Studies, vol. 57, no. 2, pp. 397421.

Moor, N., Brown, R., Taggart, L., Fernandez, A. \& Coen, S. 2010, "Intergroup identity perceptions and their implications for intergroup forgiveness: The Common Ingroup Identity Model and its efficacy in the field.", Irish Journal of Psychology, vol. 31, no. 3-4, pp. 151170.

Moxon-Browne, E. (1991). National identity in Northern Ireland. Social Attitudes in Northern Ireland, 23-30. 
Muldoon, O., Trew, K. J., Todd, J., Rougier, N., \& McLaughlin, K. (2007). The nature of meaning of identity in Northern Ireland after the Belfast good Friday agreement.

Muldoon, O. T., Schmid, K., \& Downes, C. (2009). Political violence and psychological Well-Being: The role of social identity. Applied Psychology, 58(1), 129-145.

SDLP 2016, A United Ireland and the Agreement. Available: http://www.sdlp.ie/site/assets/files/1008/sdlp210305unity.pdf.

Sindic, D., \& Reicher, S. D. (2008). The instrumental use of group prototypicality judgments. Journal of Experimental Social Psychology, 44(6), 1425-1435.

Smith, A. D. (1991). National identity University of Nevada Press.

Southern, N. 2005, "Ian Paisley and evangelical Democratic Unionists: An analysis of the role of evangelical Protestantism within the Democratic Unionist Party", Irish Political Studies, vol. 20, no. 2, pp. 127-145.

Stalin, J. (1913). Marxism and the national question, International Bookshop.

Taylor, P. 2014, The Provos: The IRA and Sinn Fein, A\&C Black.

Todd, J. (1987). Two traditions in unionist political culture. Irish Political Studies, 2(1), 1-26.

Todd, J., O'Keefe, T., Rougier, N., \& Bottos, L. C. (2006). Fluid or frozen? Choice and change in ethno-national identification in contemporary Northern Ireland. Nationalism and Ethnic Politics, 12(3-4), 323-346.

Tonge, J. \& Gomez, R. 2015, "Shared Identity and the End of Conflict? How Far Has a Common Sense of 'Northern Irishness' Replaced British or Irish Allegiances since the 1998 Good Friday Agreement?" Irish Political Studies, , no. ahead-of-print, pp. 1-23.

Trew, K. 1998, "The northern Irish identity", A question of identity, pp. 60-76.

Waddell, N. \& Cairns, E. 1991, "Identity preference in Northern Ireland", Political Psychology, pp. 205-213.

Walker, G. 2004, A History of the Ulster Unionist Party: Protest, Pragmatism and Pessimism, Manchester University Press. 
Wenzel, M., Mummendey, A., \& Waldzus, S. (2008). Superordinate identities and intergroup conflict: The ingroup projection model. European Review of Social Psychology, 18(1), 331372.

Whyte, J. 1991, Interpreting Northern Ireland, Clarendon Press. 